\title{
PENGARUH BULLYING TERHADAP HUBUNGAN ANTAR MANUSIA
}

Adminitrasi Pendidikan, Fakultas Ilmu Pendidikan, Universitas Negeri Padang,

Kota Padang

E-mail: Robiprtatama.rp7@gmail.com

Abstrak

Bullying ini merupakan salah satu bentuk kekerasan yang Pada masa sekarang banyak terjadi kekerasan, salah satu dilakukan seseorang kepada orang lain. Terdapat beberapa cara dan bentuk dari bullying diantaranya bullying secara langsung dan tidak langsung, bullying fisik, verbal, dan non verbal. Adapun komponen bullying yaitu, terdapat pelaku bullying, korban bullying, dan partisipan. Ada beberapa faktor yang mempengaruhi bullying diantaranya faktor individu dan faktor lingkungan. Tindak bullying dapat berdampak negatif bagi sipelaku, korban, maupunsaksi. Bullying dapat memicu problem emosional seperti: depresi, cemas, kesepian, rendah diri, dan lain-lain. Dalam hal ini sebuah hubungan antar manusia bisa menjadi tidak baik dan tidak benar di karenakan dampak bullying ini. Didalam sebuah organisasi tidak di pungkiri bahwa bullying ini juga terjadi bahkan dengan kadar yang lebih tinggi dan lebih keras dari pada bulliying antar anak-anak.

\section{Pembahasan}

\section{Konsep Dasar Bullying}

Bullying adalah salah satu bentuk dari agresi. Agresi adalah fenomena kompleks yang terdiri dari sejumlah perilku dari jenis yang lebih khusus. (Hall \& Lindzey, 1993).

Pengertian bullying menurut para ahli:

1. Beane (2008: 2) mengatakan bullying adalah "Overt and aggressive behavior that is intentional, hurtful and persistent (repeated). 'Maksud nya adalah suatu perilaku agresif yang disengaja menyakitkan, dan dilakukan secara persisten (berulang).

2. Levianti (2008: 3) "Bullying adalah perilaku agresi yang dapat berupa kekerasan fisik, verbal, ataupun psikologis, biasanya dilakukan secara berulang-ulang dari seseorang atau sekelompok orang yang lebih senior lebih kuat, lebih besar terhadap seseorang atau sekelompok orang yang lebih junior, lebih lemah, lebih kecil. 
3. Saat ini kita mampu melihat bahwa betapa banyak remaja yang terlibat dalam perilaku yang merugikan orang lain, termasuk vandalisme, pelecehan seksual, penggencetan atau yang biasanya dikenal dengan bullying. (Armstrong, 2009: 104)

4. Bullying itu sama dengan penganiayaan, kekerasan, atau perilaku menyakiti orang lain yang biasanya terjadi di sekolah". Prisna Adisti (2010: 85)

5. Alizamar dkk (2013: 22) bullying ini merupakan salah satu bentuk kekerasan atau perilaku agresif yang diperlihatkan atau dilakukan seorang kepada orang lain.

6. Menurut Randall ( 1997 dalam Randall, 2002 ) bullying merupakan perilaku agresif yang di sengaja untuk menyebabkan ketidak nyaman fisik maupun psikologis terhadap orang lain.

Jadi, dapat disimpulkan bahwa bullying merupakan suatu perilaku agresif yang sengaja dilakukan secara berulangulang dengan cara mengejek, memukul dan perilaku yang merugikan lainnya, sehingga korban tidak dapat membela diri.

Bullying lebih sering berupa gangguan yang ditujukan secara individu dalam bentuk gangguan-gangguan ringan dan komentar-komentar yang tidak berbahaya. Namun, karena gangguan tersebut bersifat tetap dan tanpa menunjukkan belas kasihan, maka menjadi serangan yang bersifat agresif. Wharton (2009: 7).

Bullying bisa langsung maupun tidak langsung. Bentuk-bentuk langsungnya termasuk serangan fisik atau verbal dan pengasingan relasional atau social. Bullying tidak langsung (misalnya, menyebarkan rumor jahat atau merusak barang kepunyaan) termasuk, yang lebih mutakhir, cyberbullying, yaitu bullying menggunakan telepon seluler atau internet. Smith et al (dalam Geldard, 2012: 172).

Nansell dkk (2001, dalam Maliki, 2009) menyatakan bahwa bullying termasuk bullying secara fisik (memukul, menendang), bullying verbal (misalnya olok-olok, ancaman), manuver psikologis (misalnya: rumor, pengucilan), segala jenis perilaku yang memebahayakan atau mengganggu diamana perilaku tersebut berulang dalam waktu yang berrbeda.

Bentuk lain dari bullying merusak barang milik orang lain, mengucilkan teman, dan menyebarkan gossip. Belakangan ini, bullying juga dapat dilakukan melalui SMS atau e-mail. Femi Olivia (2009: 157) 
Beane ( 2008 : 3-6 ) perilaku bullying terbagi atas beberapa bentuk:

1. Fisik

2. Hitting, slapping, elbowing, and slamming

3. Pushing, shoving and traping

4. Kicking

5. Taking or stealing

6. Restraining

7. Pinching

8. Menjejal seseorang di dalam loker

Selanjutnya, Rigtby ( 2007: 20) menyatakan perilaku bullying adalah sebagai berikut:

1. Bullying fisik

Bentuk perilaku bullying fisik yang dilakukan secara langsung antara lain adalah memukuli, menendang, meludahi, dan melempar dengan barang, sedangkan yang dilakukan tidak langsung adalah meminta orang lain untuk menyergap seseorang.

2. Bullying verbal

Bullying verbal merupakan perilaku yang mudah untuk dilakukan oleh perempuan atau laki-laki. Dapat berupa julukan, fitnah, celaan, penghinaan, menuduh, menyoraki, mengolok-olok. Selain itu dapat berupa meneror lewat telepon atau surat yang berisi ancaman.

Colorosa (dalam Hengki Yandri dkk, 2013: 99) Bentuk perilaku bullying verbal yang dilakukan secara langsung antara lain adalah penghinaan secara lisan, dengan memanggil julukan buruk, sedangkan yang dilakukan secara tidak langsung adalah meminta orang lain untuk menghina seseorang. Bentuk perilaku bullying non verbal yang berdampak secara psikologis yang dilakukan secara langsung antara lain adalah mengancam dan isyarat cabul, sedangkan yang dilakukan secara tidak langsung adalah mengucilkan atau mengeluarkan seseorang dari kelompok.

Dan menurut Blatcford (dalam geldard.K ,2012:175) bullying oleh siswa terhadap siswa lain kebanyakan terjadi diluar kelas, di koridor, halaman sekolah, dan di luar gerbang sekolah. Bullying bentuk ini adalah bullying yang paling berbahaya karena sulit terdeteksi dari luar. Seperti memandang dengan sinis, menampilkan ekspresi wajah yang merendah, menjulurkan lidah, memandang dengan penuh ancaman, mempermalukan seseorang di depan umum, mengisolir, menjauhkan, dan banyak perilaku lainnya. Yayasan Semai Jiwa Insani 
(dalam Hengki Yandri dkk, 2013: 99)

Dan, Ahmad Baliyo ( 2011 : 20 )

menyatakan bullying dapat terjadi dimana-

mana antara lain sekolah, kampus, tempat kerja dan sebagainya. Sangat banyak cara seseorang dalam melakukan bullying baik secara fisik maupun psikologis. Dan bentuk bullying pun sangat banyak pernyataan ini didukung oleh Andri Priyatna (2010:11) mengemukakan bahwa bullying pun dapat berwujud agresi tidak langsung, seperti: menggosipkan seseorang di belakangnya, sengaja tidak mengajak dia dalam aktivitas sosial, dan lain.lain.

\section{Konsep Dasar Hubungan Antar Manusia}

Hubungan antar manusia adalah semua jenis ikatan baik, buruk, yang di jalin oleh manusia dengan manusia lainnya baik secara formal, informal, maupun nonformal. menurut Sarwoto 1991 (Ermita Volume XII No.2 2012) HAM adalah keseluruhan hubungan baik yang formal maupun informal yang perlu diciptakan dan dibina dalam suatu organisasi sedemikian rupa sehingga tercipta iklim kerja yang intim dan harmonis dalam rangka pencapaian tujuan yang telah ditentukan. Selanjutnya menurut Effendy 1993 (Ermita Volume XII No. 2 2012) menyatakan bahwa: Hubungan antar manusia pada dasarya disebut juga dengan istilah Human Relations, pemberian makna terhadap proses rohaniah yang tertuju kepada kebahagian dan kepuasan yang berdasarkan watak, sifat, perangai, kepribadian, tingkah laku dan lain-lain aspek kejiwaan yang terdapat pada diri manusia. Selanjutnya Hasibuan 2005 (Ermita Vol XII No.2 2012) mengatakan bahwa hubungan antar manusia adalah "hubungan kemanusiaan yang harmonis, tercipta atas kesadaran dan kesediaan melebur keinginan individu demi kepentingan bersama. Kemudian Siagian 1999 (Ermita Vol XII No.2 2012) menjelaskan bahwa hubungan antar manusia adalah keseluruhan rangkaian hubungan yang bersifat formal antara atasan dengan bawahan, atasan dengan atasan, serta antara bawahan dengan bawahan lain yang harus dibina dan dipelihara sedemikian rupa, sehingga tercipta suatu team work dan suasana kerja yang intim dan harmonis dalam rangka pencapaian tujuan. Dari Pengertian di atas dapat di tarik kesimpulan Hubungan antar manusia Merupakan Keseluruhan Hubungan baik formal maupun informal yang perlu di ciptakan dalam sebuah kerja sama di dalam organisasi baik antara pimpinan dengan bawahan, maupun antara sesama karyawan.

Effendy 1993 (Ermita Vol XII No.2 2012) mengemukakan ada dua pengertian hubungan antar manusia, yakni hubungan 
dalam arti luas dan arti sempit. Dalam arti luas hubungan antar manusia adalah :komunikasi persuasif yang dilakukan seseorang kepada orang lain secara tatap muka dalam segala situasi kehidupan, sehingga menimbulkan kebahagiaan pada kedua belah pihak yang dilakukan di mana saja dan kapan saja serta dalam semua aspek kehidupan. Sedangkan hubungan antar manusia dalam arti yang sempit yaitu : komunikasi persuasif yang dilakukan seseorang kepada orang lain secara tatap muka dalam situasi kerja (work situation) dan dalam organisasi kekaryaan (woerk organization untuk menggugah kegairahan dan kegiatan untuk bekerja dengan semangat kerjasama yang produktif dengan perasaan bahagia dan puas hati.

Menurut Ermita dalam jurnalnya mengatakan bahwa hubungan antar manusia adalah kegiatan komunikasi persuasif yang bukan hanya sekedar relasi atau hubungan saja melainkan suatu aktivitas dan suatu kegiatan untuk mengembangkan rasa bahagia dan rasa puas, serta kegiatan untuk meningkatkan dan mengembangka lebih produktif dan memuaskan. Komunikasi persuasif yang dimaksud di sini adalah komunikasi yang bersifat membujuk agar tercipta hubungan yang baik. Dari pengertian ini dapat kita artikan bahwa di dalam sebuah hubungan di butuhkan komunikasi yang baik dan bukan hanya hubungan relasi saja tetapi sebuah hubungan yang meningkatkan rasa puas dan menyenangkan.

Menurut Siagian (1999:92) sepuluh prinsip tersebut adalah: a) Harus ada singkronisasi antara tujuan denga tujuantujuan individu didalam organisasi, b) Suasana kerja yang menyenangkan, c) Informalitas yang wajar dalam hubungan kerja, d) Manusia bawahan bukan mesin, e) Kembangkan kemampuan bawahan sampai tingkat yang maksimal, f) Pekerjaan yang menarik penuh tantangan, g) Pengakuan dan penghargaan atas pelaksanaan tugas yang telah dilakukan dengan baik, h) Alat perlengkapan yang cukup, i) Menempatkan orang pada tempat yang tepat, j) Balas jasa harus seimbang dengan jasa yang diberikan.

\section{Pengaruh Bullying Terhadap Hubungan Antar Manusia}

Bullying sering terjadi pada kehidupan sehari-hari. Biasanya bullying terjadi karena adanya rasa tidak suka dan rasa ingin menjatuhkan orang lain. Di dalam sebuah pekerjaankita di tuntut untuk saling bekerja sama, saling berhubungan antar anggota organisasi. Di dalam bekerja dan berhubungan dengan sesame anggota, tidak 
jarang terjadi bullying. Bullying ini bersifat psikis maupun fisikis.

Hal-hal kecil yang tampa kita sadari merupakan sebuah tindakan bullying sering kita lakukan dalam kehidupan berorganisasi, seperti contohnya mengatai teman kita tidak becus dalam bekerja atau memberikan ejekan. Tampa kita sadari hal ini berpengaruh pada pekerjaan, hubungan antar manusia dan keharmonisan kita dalam sebuah organisasi.

Secara konseptual ada banyak dampak yang di sebabkan oleh bullying terhadap hubungan antar manusia salah satunya serangan psikis seperti rasa tidak senang, rasa frustasi, rasa dendam dan bahkan bisa menyebabkan pertentangan antar manusia. Hal ini di perjelas oleh pendapat para ahli seperti berikut Luthar (2006) menujukan gangguan yang berat. gangguan psikis juga di alami oleh anak yang hadir di sekolah walaupun tidak secara langsung tidak menyasikan kekerasan yang di lakukan tehadap teman-teman mereka. Bullying memiliki dampak fisik dan psikologis, secara fisik Sulvivan (200:27) menjelaskan bahwa perilaku bullying di antaranya adalah dampak yang mengakibatkan sakit secara fisik. Tindakan bullying merupakan masalah yang dampaknya harus dirasakan oleh semua pihak baik pelaku, korban, maupun orangorang yang menjadi saksi tindakan tersebut. (Andri Priyatna, 2010: 2).

Dari pendapat para ahli dapat kita lihat bahwa banyak sekali pengaruh bullying terhadap hubungan antar manusia, seperti :

1. Depresi

2. Cemas

3. Ketakutan

4. Dendam

5. Rasa ingin membalas

6. Dll

Kesimpulan

bullying merupakan suatu perilaku agresif yang sengaja dilakukan secara berulang-ulang dengan cara mengejek, memukul dan perilaku yang merugikan lainnya, sehingga korban tidak dapat membela diri. Hubungan antar manusia adalah semua jenis ikatan baik, buruk, yang di jalin oleh manusia dengan manusia lainnya baik secara formal, informal, maupun nonformal. Bullying dapat menyebabkan hubungan antar manusia menjadi renggang karna ada rasa tidak senang yang muncul karna seringnya terjadi bullying ini.

Saran

Di harapkan dalam sebuah organisasi terjalin hubungan antar manusia yang 
harmonis dan baik. Salah satu caranya adalah dengan cara menghilangkan kebiasaan bullying dalam hubungan antar manusia. Karna bullying ini dapat merusak keharmonisan di dalam organisasi.

Di dalam artikel ini masih banyak kekurangan dan di harapkan saran perbaikan dari semua pihak.

Daftar Pustaka

\section{DAFTAR PUSTAKA}

1. Adisti, Prisna. 2010. Personaliy Plus For Teens. Yogyakarta: Galangpress.

2. Alizamar, Riri Yunika, \& Indah Sukmawati. 2013._"Upaya Guru Bimbingan Dan Konseling Dalam Mencegah Perilaku Bullying Di Sma Se Kota Padang”. Jurnal Ilmiah Konseling. Vol. 2. No. 21-25.

3. Ali, Muhatdi. (2006). Penanaman Nilai-Nilai Agama Dan Pembentukan Sikap Serta Perilaku Siswa Sekolah Dasar. Jurnal Prima Edukasia (No.1 :2006). Hlm 2

4. Allan, Beane . 2008 . Protect You Child From Bullying . San Fransisco: Jossey Bass A Wiley Imprint.

5. Amini. 2008. Bullying: Mengatasi Kekerasan Disekolah Dan Lingkungan. Jakarta: Grasindo.
6. Ariesto , A. 2009. Pelaksanaan program anti bullying teacher empowerment juni 12, 2017, from

7. Desmita. (2005). Psikologi Perkembangan. Bandung: PT Remaja Rosdakarya.

8. Djuwita, R, 2007, bullying: kekerasan terselubung di sekolh, http://www.anakku.net, di akses 19 Mei 2019.

9. Ermita. 2012. Hubungan antar manusia. Jurnal Ilmiah Fakultas Ilmu Pendidikan Vol XII No.2. Padang

10. Femi, Olivia . 2009. Kembangkan Kecerdikan Anak Dengan TaktikBiosmart. Jakarta: Elex Media Komputindo.

11. Fitrian saifullah. Hubungan antara konsep diri dengan bullying pada siswa-siswi SMP, e juornal psikologi, 2016 h.205

12. Gordon, Alexa. 2009 . Dealing With Bullying . Newyork: Chelsea HousePublisher.

13. Hall, calvin S.,\& Gardner Lindzey. 1993. Psikologi Kepribadian 1: Teori-Teori Psikodinamik (Klinis). Yogyakarta: Kanisius.

14. Hamburg, da.,\& hamburg, B.A.(2004). Learning To Life Together : Preventing Hatred Adn 
Violence In Child And Adolescence

Development. New York. Oxford University Press.

15. Huraerah, Abu. (2012). Kekerasan Terhadap Anak. Bandung: Nuansa Cendekia.

16. Kartono, Kartini. 2013. Patologi Sosial: Gangguan Gangguan Kejiwaan. Jakarta: Raja Grafindo Persada. 